\title{
Long-term food waste management in Phnom Penh utilizing a system dynamics modeling approach
}

\author{
Thanwadee Chinda ${ }^{\dagger}$, Sireiratana Thay \\ School of Management Technology, Sirindhorn International Institute of Technology, Thammasat University, Tiwanont Road, Bangkadi, Muang, \\ Pathum Thani, 12000 Thailand
}

\begin{abstract}
Phnom Penh has a high number of people. With more people, it is expected that food waste issues will be severe. To properly manage food waste, it is necessary to identify the key factors affecting food waste management, and examine the interactions among those key factors to effectively plan for long-term management. This study develops a dynamics model of food waste management, considering vegetables as the main waste, to examine the trends of food waste in Phnom Penh and plan for long-term management. The developed dynamics model considers two types of waste, household and retailer wastes. The simulation results reveal that most food wastes are from households. They are mainly from preparation processes and inappropriate packing sizes. The results show that with a smaller percentage of waste in preparation processes, food wastes going to a landfill decrease. The use of smaller-size packs ( $250 \mathrm{~g}$ and $350 \mathrm{~g}$ ) also helps to minimize food wastes. The simulation results also suggest the use of biodigesters, to convert food waste to energy and reduce landfill waste in the long term. Local communities, local authorities, and governments can use this study to plan for long-term food waste management, to reduce food waste and mitigate landfill problems.
\end{abstract}

Keywords: Anaerobic digestion, Composting, Domestic bio-digester, Food waste management, System dynamics modelling, Vegetables

\section{Introduction}

Phnom Penh, the capital city of Cambodia, has a high growth rate, with an average rate of increase of $12.4 \%$ [1]. It is a city with a large number of immigrants, with a growth rate of about $3.2 \%$ per year [2]. With a high number of people, the municipal solid waste is expected to increase. In 2013, the average municipal solid waste (MSW) in Phnom Penh per day was about 1,550 tonnes, or about $0.91 \mathrm{~kg}$ of waste generated per person per day [3]. Waste generated in Phnom Penh is mainly dumped into the Dangkor landfill, which is around $15 \mathrm{~km}$ from the city [3]. The landfill has recently faced many problems, such as groundwater contamination and greenhouse gas effects from a high amount of food waste.

The composition of MSW varies significantly from one municipality to another and from country to country. Generally, it is composed of food, paper, plastic, yard trimmings, metal, wood, and glass [4]. Singh et al. [5] stated that more than half (51.9\%) of the MSW in Phnom Penh, Cambodia, was from food waste. Seng et al. [6], similarly, mentioned that $63.3 \%$ of the MSW in Phnom Penh was from food waste. Ho and Chu [7] mentioned that food wastes comprised nearly $40 \%$ of the MSW generated in Hong Kong. Sang-Arun et al. [8] investigated waste compositions in four major cities, including Phnom Penh, Battambang, Siem Reap, and Kampong Cham in Cambodia. They concluded that food (64\%), plastic (10\%), wood (6\%), paper (4\%), glass $(3 \%)$, metal $(2 \%)$, textile $(2 \%)$, and others (9\%) were the major components of MSW.

Food waste is a huge issue worldwide, as one-quarter of consumable food is wasted each year [9]. It consists of, for example, vegetable, fruit peelings, meat, poultry, and fish. Sang-Arun et al. [8] mentioned that about $76 \%$ of food wastes in Cambodia contained vegetables, fruits, sugarcane, maize, and coconut shells. Food waste is generated in many different sectors, such as wet markets, hotels, restaurants, and housing estates. It can be categorized into pre-consumption and post-consumption food wastes [7]. Pre-consumption food waste refers to the food waste generated during food preparation and unused food discarded before human consumption. Some examples are peelings, apple cores, bones, eggshells, and coffee grounds. Post-consumption food waste is left-
This is an Open Access article distributed under the terms of the Creative Commons Attribution Non-Commercial License (http://creativecommons.org/licenses/by-nc/3.0/) which permits unrestricted non-commercial use, distribution, and reproduction in any medium, provided the original work is properly cited.
Received Novermber 02, 2020 Accepted December 14, 2020

${ }^{\dagger}$ Corresponding author

E-mail: thanwadee@siit.tu.ac.th

Tel: +662-5013505 (ext. 6007) Fax: +662-5013505 (ext. 6014) 
over food after processing or cooking [7]. Singh et al. [5] mentioned that households, shops, and markets contribute almost $70 \%$ of the food waste in Phnom Penh.

Food waste causes various environmental issues, such as methane emissions, air pollution, and water contamination [10]. In 2013, the methane emissions in Cambodia expanded by $5.0 \mathrm{Gg}$ per tonne. With more food waste dumped into landfills, it is expected that the methane emissions will reach $12 \mathrm{Gg}$ per tonne in 2030, causing serious global warming issues in the country [11]. Proper food waste management is, therefore, needed to effectively plan for long-term management, to reduce possible environmental impacts.

Various methods can be used to manage food wastes. Sang-Arun et al. [12] listed the waste utilization and treatment technologies in Cambodia, Lao, and Thailand, including animal feeding, composting, anaerobic digestion, sanitary landfill, incineration, and mechanical biological treatment. Seng et al. [13] commented that organic waste separation is only performed by individual families for the animal feed. Because of the availability of marketable animal feed, difficulty of food waste transport, and the speed of animal production, using food waste for animal feed has become less attractive in Phnom Penh. Seng et al. [14] mentioned landfilling, composting, landfilling, incineration, and recycling as methods for waste management in Cambodia. NBP [15] encouraged households in Cambodia to use biodigesters to achieve economic, health, environmental, and social benefits. Zulkepli et al. [16] suggested that composting and anaerobic digestion are feasible alternatives to landfilling in a community in Malaysia. Chen [17] added that composting food waste in Taiwan yields the most benefits, compared to other applications.

This study examines food waste management in the long term, utilizing the system dynamics (SD) modeling approach. Only vegetables from households and retailers are considered as sources of food wastes in the dynamics model development in this study, as most dishes cooked in Cambodia contain vegetables. Four methods of food waste management in Cambodia are considered in the dynamics model development, including composting, anaerobic digestion, use of biodigesters, and landfilling. This study shows key factors affecting food waste management, and provide strategies to effectively manage food waste and reduce the environmental impacts in Phnom Penh in the long term.

This study reviews food waste management in Cambodia and other countries to extract key factors affecting food waste management. Secondary and primary data are gathered to be used for the dynamics model development. Secondary data are collected from various sources, such as international journals, company reports, and government-related websites. Examples of data are the number of people, family sizes, and prices. Interviews and observations are used for primary data collection. The dynamics model of food waste management is then developed, based on the collected secondary and primary data. The model is simulated, and the simulation results show the trends of food waste in Phnom Penh, Cambodia, in the long-term. Sensitivity analysis is then performed to examine various strategies and methods to reduce the amount of food waste in the long-term.

\section{Literature Review}

\subsection{Trends of Food Waste in Phnom Penh}

The rate of waste generation per capita in Phnom Penh was more than $0.74 \mathrm{~kg} / \mathrm{d} /$ person in 2003, and is expected to increase to 1.24 $\mathrm{kg} / \mathrm{d} /$ person by 2030 [18]. This represents an increase in the daily waste generation of about $12.1 \%$, leading to the waste generation of around 2,200 tonnes/d in 2020 [19].

In Cambodia, popular dishes that are usually cooked always contain vegetables, which are cheap and always on promotions. This causes a large amount of food waste. Vegetables may be cut and peeled for the edible parts, leading to more trash. Cambodian people usually cook stir-fried and soup dishes with various kinds of vegetables. According to Nomadicboys [20], Lok Lak is a common Cambodian stir-fried beef dish served with cucumbers, tomatoes, and lettuce. Cha Tra Kuen is another popular stir-fried dish served with morning glory [21]. Trey Cha Cho Em is a popular fish dish, deep fried with tomatoes, carrots, and lettuce [22]. Somlor Machou Kroeung is a delicious soup, with morning glory and capsicum as the main ingredients [23] (see Fig. 1). In this study, the vegetables used in common dishes are considered as sources of food wastes.

\subsection{Methods for Food Waste Management in Phnom Penh}

Based on the literature, four methods are commonly used in food waste management in Cambodia include composting, anaerobic digestion, use of biodigesters, and landfilling [6, 8, 12, 15].

\subsubsection{Composting}

Composting is a technique to enhance the degradation of organic matter under aerobic conditions [12]. It can reduce the volume of waste by about $30-50 \%$. Compost, the residue product, can also be used as a soil fertilizer. Seng et al. [13] mentioned that composting is recommended by the Phnom Penh municipality as the first recommended technique of food waste management. Sang-Arun et al. [12] stated that this technique is uncomplicated, and may be an

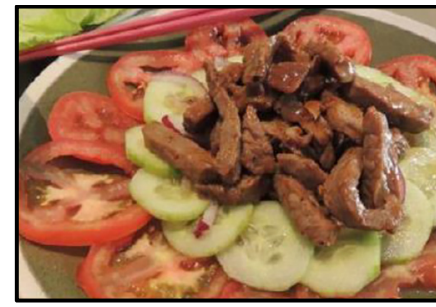

Lok Lak

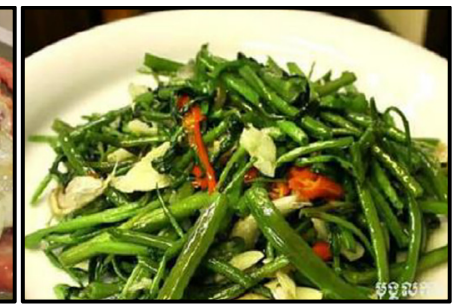

Cha Tra Kuen

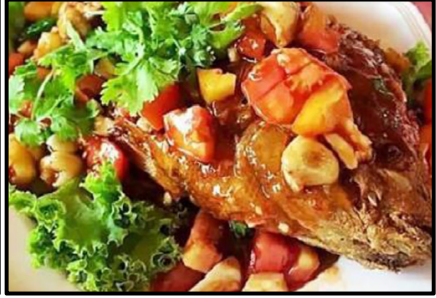

Trey Cha Cho Em

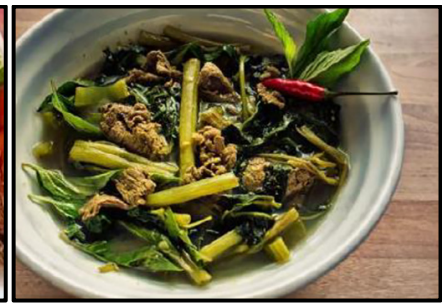

Somlor Machou Koreung

Fig. 1. Popular dishes in Cambodia. 
economical alternative for many municipalities in Cambodia. It can be applied at various scales, from individual households to large centralized facilities. However, foul odors and vector-borne diseases are major limitations of this technique. The complexity of discharged waste also makes composting difficult [12, 13].

In this study, a small-scale, manually operated composting plant is considered, and organic fertilizer is made and sold in the community.

\subsubsection{Anaerobic digestion}

Anaerobic digestion is the process of breaking down organic material in the absence of oxygen. It takes organic material from a variety of sources, including food waste, producing biogas to be used to produce heat and electricity [24]. Zulkepli et al. [16] mentioned that anaerobic digestion produces biogas and digestate, which is the solid and/or liquid residual material remaining after the organic material has been digested. The digestate can be further processed as fertilizer, and sold to gain income for a community [16]. Joshi and Visvanathan [25] added that anaerobic digestion is now the preferred option of food waste management in Asia, considering the characteristics of the available food waste in Asia and the underlying environmental and economic benefits.

Sang-Arun et al. [8] mentioned that anaerobic digestion has many advantages over composting in terms of products and types of waste inputs. It also generates fewer odors and requires less space than composting. However, the cost of building an anaerobic digestion facility is high, and the environmental impact of transporting the organic wastes to the facility makes it difficult to implement [24]. Zulkepli et al. [16] stated that the capital cost of building an anaerobic digestion system is almost 10 times higher than that of building a composting system.

In this study, the digestate is from anaerobic digestion, and every 1 tonne of food waste can produce 0.2 tonne of fertilizer [16]. Biogas achieved from the anaerobic digestion process is used to produce electricity that is used in the community.

\subsubsection{Domestic Biodigesters}

NBP [15] established a national domestic biodigester sector in Cambodia. Currently, there are over 28000 biodigesters, representing $6 \%$ of potential households in Cambodia. There are different types of small-scale biodigesters, including fixed dome, floating drum, low-cost polyethylene tube, balloon, horizontal, earth-pit, and ferro-cement [26]. The most widely used model in Cambodia is the fixed dome digester [15]. It consists of a digester with a fixed non-moveable gas holder, which sits on top of the digester. Renewable energy, generated by this biodigester, includes methane and bio-slurry gas that are mainly used in cooking and lighting [15]. The use of a biodigester brings a number of benefits, such as saving expenditures on fuel sources, improving household sanitation, reducing greenhouse gases, and enhancing the prestige of a community [8].

\subsubsection{Landfilling}

The main landfill site in Phnom Penh is in Dangkor district, where wastes from households, industries, and hospitals are dumped. The amount of waste transported to the Dangkor landfill has increased by an average of $12 \%$ per year. Fakhry [27] mentioned that about one million tonnes of waste were disposed of in the
Dangkor landfill in 2019. This leads to serious global warming through methane emissions at the landfill, as methane is equivalent to 21 times that of carbon dioxide for greenhouse gas emissions [8]. Sang-Arun [8] stated that the disposal of food waste at a landfill should be avoided, as it may create soil, water, and air pollution, causing odors and generating disease carriers.

\subsection{Factors Affecting Food Waste Management}

Many research studies have been conducted in the area of waste management, including food waste management. Pai et al. [28], for example, studied the impacts of increasing population on the amount of waste generation using the system dynamics approach. They concluded that more people led to more wastes, and that action should be taken to reduce waste by raising awareness and promoting recycling habits. Oh and Lee [29] explored an environmentally innovative and low-impact technology, a zero-food waste system for sustainable residential buildings in urban areas of Korea. The system utilizes food waste by converting it into compost or biofuels, reducing carbon emissions. Romo-Rábago [30] evaluated the feasibility of implementing a low-cost biodigester at the Jiudao Yakou village in China, utilizing food waste as one of the sources. They concluded that the installation of a low-cost biodigester has multiple environmental and socio-economic benefits, such as deforestation reduction, annual greenhouse gas emission reduction, and energy savings. Žitnik and Vidic [31] mentioned that food waste may occur during food preparation. Up to $11 \%$ of total ingredients may be wasted during the preparation processes. Schanes et al. [32] reviewed empirical studies on food waste practices and factors fostering and impeding the generation of food waste at the household level. They summarized that people often buy more food than needed. Promotional offers promote the wasting of food, improper storing food products results in more food waste, and reusing leftovers is considered an effective strategy to combat food waste at the household level.

In Cambodia, a number of studies have been conducted in the area of waste management. Mongtoeun et al. [33], studied household solid waste generation and socioeconomic factors in the capital city of Cambodia. They concluded that larger household sizes and more family members result in higher waste generation. Kum et al. [34] recommended strategies to improve solid waste management in Phnom Penh by, for example, introducing appropriate storage systems, enhancing local waste authorities, and sharing information among relevant waste agencies. Bandith [35] assessed household solid waste management based on public behaviors using system dynamics modeling in Phnom Penh. They concluded that household size and economic factors determine the waste generation rate. The government and service providers should provide waste management at the desired tipping fee to avoid illegal disposal.

In this study, 15 factors influencing food waste management are extracted from the waste-related literature and used for the development of the dynamics model of food waste management. Details are as follows.

1) Population: With a high growth rate, waste generation can be severe [28, 36].

2) Family size: There are two common sizes of a family: smalland large-sized families. Small-sized families in Cambodia tend to increase by $2.7 \%$ per year due to changes in lifestyle [1]. 3) Members in a family: A small-sized family has up to three 
persons, while a large-sized family has more than three persons [37-39].

4) Shopping frequency: Food waste may be reduced when householders shop more often. In this study, householders may shop with different frequencies, including once a week, twice a week, and every day [32, 40].

5) Food preparation: Food waste may occur during food preparation. According to Žitnik and Vidic (2016), up to $11 \%$ of total ingredients are wasted during the preparation processes [31, 41].

6) Packing size: Around $20-25 \%$ of food waste is from mismatched packing sizes. Various packing sizes may help to reduce wastes [38, 42].

7) Order quantity: The proper order quantity, especially with short-life products, helps retailers to reduce waste [43, 44].

8) Promotions: Promotions of near due-date and oversupplied products may help to reduce waste. However, some promotions, such as "buy 4 get 1 free" and "buy 1 get 1 free" may result in higher food wastes. Householders may not be able to consume the products with this promotion before their expiration dates [28, 37, 43-47].

9) Shelf life: Fruits and vegetables have a short life, with an average of one week [48].

10) Stock rotation: The first-in-first-out method is commonly used with short-life products, including fruits and vegetables [49-50].

11) Prices: Increases in product prices reduce consumption rates [44].

12) Composting: A small-scale composting plant is operated by the Cambodian Education and Waste Management Organization. The annual production is more than 200 tonnes/year [14]. The capital investment of a composting plant is about 10 times lower than that of an anaerobic digestion plant [16, 17].

13) Anaerobic digestion: Anaerobic digestion produces biogas (consisting primarily of methane and carbon dioxide) and digestate. Biogas can be used to generate electricity and heat, while the digestate produced can be used as compost or further processed as fertilizer [16].

14) Biodigester: A biodigester converts food waste into energy. The use of a biodigester could save up to $57 \%$ of the electricity cost [30, 51, 52].

15) Landfilling: Landfilling is a common practice in Cambodia $[8,12]$. The government and service providers should provide waste management at the desired tipping fee [35].

\subsection{System Dynamics Modeling Approach}

System dynamics (SD) modeling is used to develop the dynamics model of food waste management in this study. It is an approach for modeling and analyzing complex behaviors of social systems through feedback loops. Dyson and Chang [53] mentioned that SD helps to advance preparation, with successful instruments for better agreement with complex management issues. The approach has been applied in various studies, such as hospital, environment, production, and construction studies. Kum [54], for example, utilized the SD modeling approach to examine the dynamics of a bio-economic system in Cambodia. Nhim [55] developed the SD model to examine drought resilience in Cambodia. Nguyen and Chinda [56] examined the profit of residential projects in Ho Chi Minh City, Vietnam. They concluded that the average profit of the industry in the next 20 years will reach $35 \%$, with minimum and maximum percentages of $19 \%$ and $41 \%$, respectively.

The SD modeling approach is also widely used in waste-related studies. Chaerul et al. [57], for example, utilized the SD approach to examine interacting factors in a hospital waste management system in Jakarta, Indonesia. They concluded that proper waste generation is needed to reduce public health risks. Kollikkathara et al. [58], developed an SD model to examine the interactions among landfill capacity, environmental impacts, and financial expenditure, to better plan for an urban waste management system in Newark, USA. Sukholthaman and Sharp [59] developed an SD model to assess the impacts of MSW separation in Thailand. They suggested better conditions for waste collection and transportation. Manasakunkit and Chinda [60], similarly, developed an MSW dynamics model to examine the MSW in Bangkok, Thailand, in the long-term.

In this study, the SD modeling approach is used in the dynamics model development, based on the following reasons.

- Key factors affecting food waste management often involve changes, such as changes in population, packing sizes, order quantities, and management policies. A change, including its effects, may cause another change (referred to as a dynamic change); this may affect the whole system. Thus, SD modeling can be used to deal with these dynamic changes.

- There is a need to investigate the interactions and causal relationships among key food waste management factors. SD modeling can be used to capture these feedback processes.

- Hard data (objective-oriented, formal, and quantitative), such as the number of people, family sizes, and shopping frequencies, and soft data (learning-oriented, intuitive, and qualitative), such as promotion schemes and stock rotation, can be used in dynamics model development.

- SD modeling can facilitate the testing of alternative strategies to manage food waste without actually having to implement them. This saves money by eliminating costs (by not implementing a strategy).

\section{Materials and Methods}

\subsection{Secondary and Primary Data Collection}

Fifteen factors that influence food waste management are used for the development of the dynamics model of food waste management. They include household and retailer perspectives of food waste. Secondary and primary data are then collected and used to develop equations in the dynamics model. Secondary data are collected from waste-related journals, such as Waste Management, Environmental Engineering Research, Journal of Material Cycles and Waste Management, and Environmental and Waste Management. Popular websites related to Cambodian food and food waste management are also reviewed, such as Bongpet, Waste Management World, and World-Population-Review. 


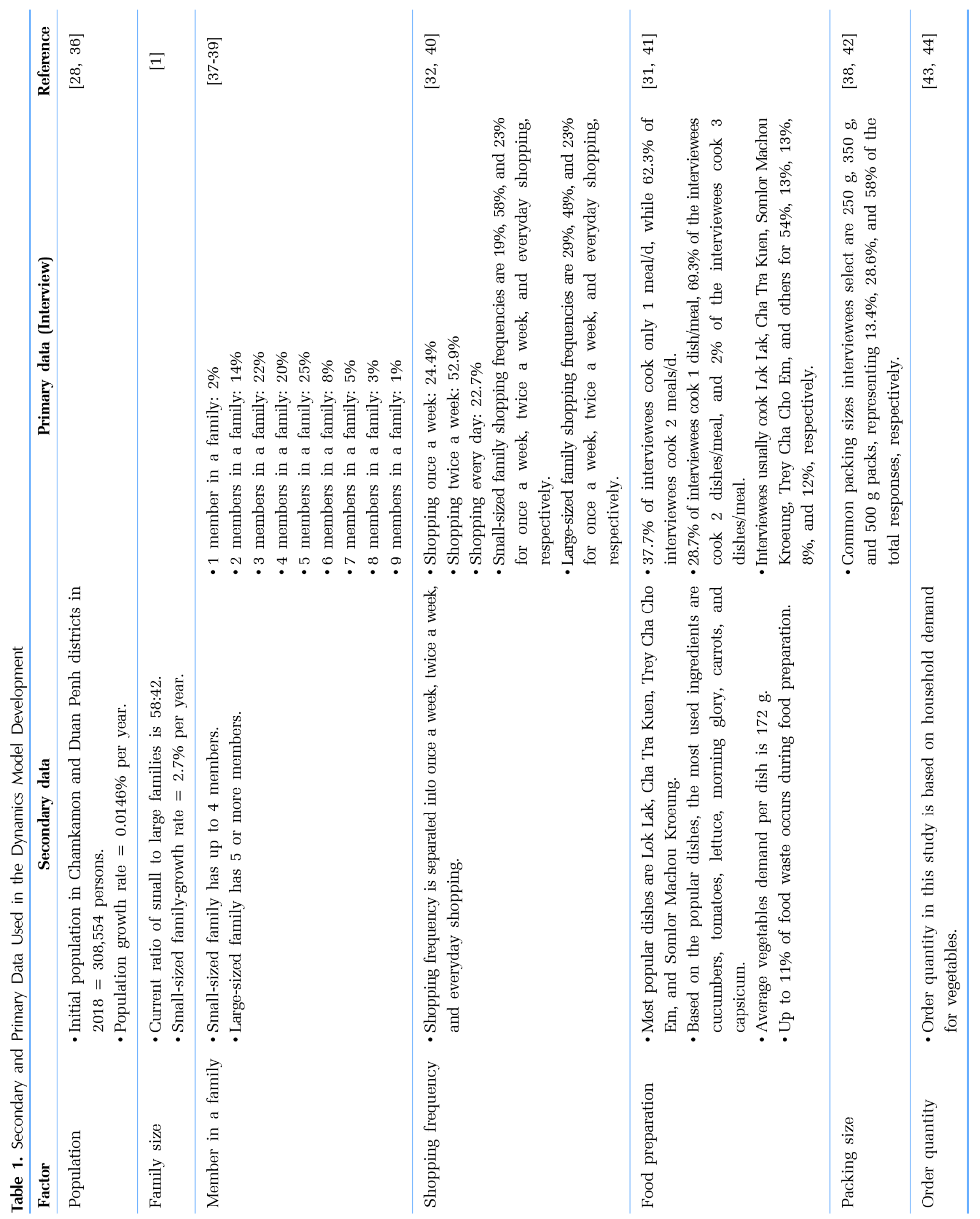




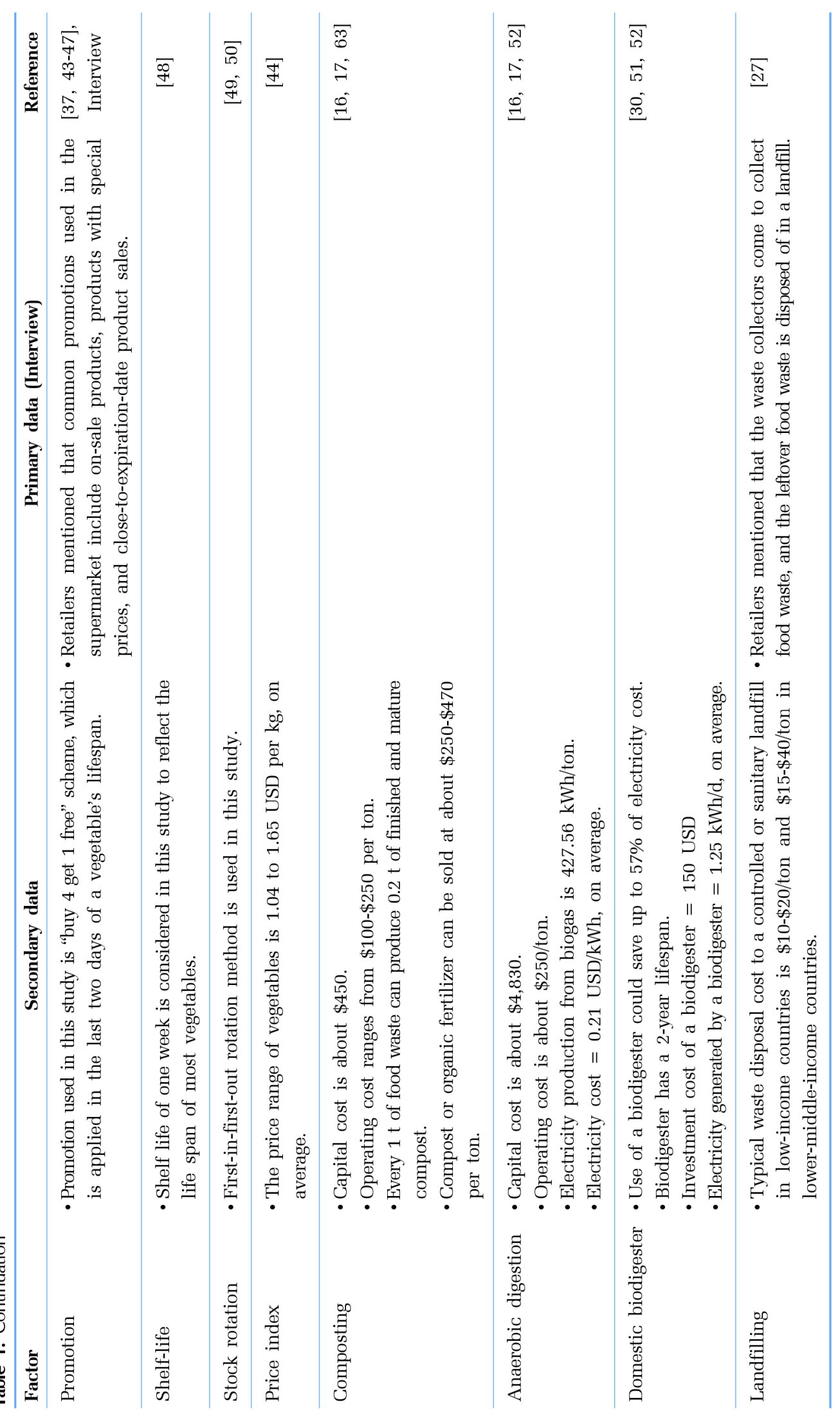


Observations and interviews are used for primary data collection. There are two types of observations from participants and non-participants [61]. In participant observations, a researcher participates in the activities of the group being observed in the same manner as its members, with or without their knowledge that they are being observed. Non-participant observations, in contrast, occur when a researcher does not get involved in the activities of the group. Kumar [61] mentioned that observations may result in observer bias and the misinterpretation of observations. In this study, non-participant observations were performed to investigate the purchasing behaviors of households at the supermarkets.

A personal interview was also performed in this study to collect primary data. It has advantages as follows.

- It allows a researcher to record verbal responses and any facial or bodily expressions. These nonverbal responses may give the researcher greater insight into the respondents' true opinions and beliefs.

- The respondents can ask for questions to be clarified.

- Researchers can ask follow-up questions to achieve more reliable data.

- Supplementary material, such as audio/video materials, can be used to increase the respondents' understanding of questions.

- The response rates are generally high [62].

Nevertheless, an interview is a time-consuming process and very costly. It may also generate interviewer bias if the interviewer is not well trained. In addition, participants may be more likely to give socially desirable responses because this is deemed appropriate by society [62].

The interviews and observations were conducted at supermarkets for a two-month period, during June-July, 2018. The interviewees were householders and retailers living in Chamkamon and Daun Penh districts. They are customers at the supermarkets who can provide such information as packing sizes, freshness, and prices of vegetables.

A total of 119 householders were included in the interviews. They were males and females with ages ranging from 20 to 35 years old. They were asked 18 questions related to 12 key factors that affect food waste. Examples of interview questions are "How many members live in your house?", "How often do you go to shop per week?", "How many meals do you usually cook per day", "What are the dishes you usually cook at home?", "What vegetables do you usually purchase?", and "What are the packing sizes of vegetables that you usually purchase?". A representative from a well-known retailer in Chamkamon and Daun Penh districts was also interviewed to gain data for the dynamics model development. Examples of interview questions are "What are the promotion schemes used in the supermarkets?", "What are common packing sizes of vegetables?", "What types of stock rotation methods are used at this supermarket?", "What are common order quantities of vegetables at this supermarket?", and "What food waste policy is implemented in this supermarket?".

The interviewees also commented that most food wastes are vegetables, as they are cheap and are always on promotion. In this study, therefore, the main vegetables that are used in popular dishes are considered as the sources of food waste.
The secondary and primary data related to key factors that affect food waste (based on household and retailer perspectives) are summarized, as shown in Table 1.

\subsection{Dynamics Model of Food Waste Management}

In this study, the SD modeling approach is used to develop the dynamics model of food waste management in Phnom Penh, Cambodia. The model consists of sub-models for household waste, retailer waste, composting, anaerobic digestion, domestic biodigesters, and landfilling. A flow chart of the dynamics model development is shown in Fig. 2.

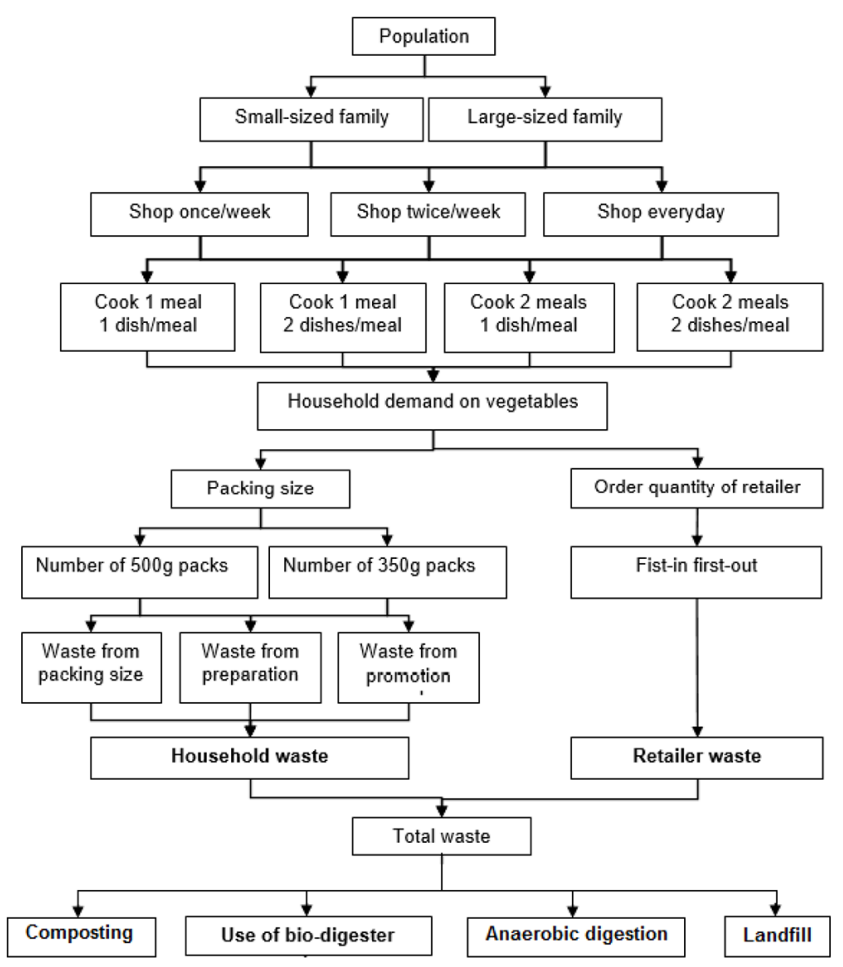

Fig. 2. Flow chart of the dynamics model development.

\subsubsection{Household waste sub-model}

Based on the interview results, households are separated into small-sized (58\%) and large-sized (42\%) families. Small-sized (nuclear) families are the societal norm in many countries. The family has up to four members, including the father, mother, and children [64]. Large-sized families consist of five or more members [65]. The households mention that they tend to shop once a week, twice a week, and every day, representing $19 \%$, 58\%, and $23 \%$ of total responses, respectively. These shopping frequencies reflect the vegetable amount each family needs from shopping. The vegetable demand also depends on the number of meals and the number of dishes, cooked per day. Based on the interviews, popular dishes that are usually cooked include Lok Lak, Cha Tra Kuen, Trey Cha Cho Em, and Somlor Machou Kroeung. These dishes need cucumbers, tomatoes, lettuce, morning glory, carrots, and capsicum.

Eq. (1) shows the vegetable demand for a small-sized family who shops every day, cooks one meal per day, and cooks only 
one dish per meal.

$$
\mathrm{VNS711SF}=\mathrm{AVD} \times \mathrm{C} 1 \mathrm{~T} 1 \mathrm{D} \times \mathrm{SF}
$$

where,

$$
\begin{aligned}
\mathrm{VNS711SF}= & \begin{array}{l}
\text { Vegetable demand for a small-sized family who } \\
\text { shops every day, cooks one meal per day, and }
\end{array}
\end{aligned}
$$
cooks only one dish per meal (g)

AVD $=$ Average vegetable portion per dish per person $(\mathrm{g})$

C1T1D = Number of dishes cooked per day, i.e., one dish per day based on one cooked meal per day and one cooked dish per meal (dishes/meal)

$\mathrm{SF}=$ Small-sized family members (persons)

Household demand for vegetables in Fig. 2 is then matched with two packing sizes available at the retailer shops. The number of purchased packs is calculated to achieve the best match with the vegetable demand. These packs, however, may lead to "waste from packing size" if the demand is not matched with the packing sizes. Eq. (2) shows an example of "waste from packing size" from a small-sized family who shops every day, cooks one meal per day, and cooks only one dish per meal. Only 350 g packs, only 500 g packs, and mixes of $350 \mathrm{~g}$ and 500 g packs are compared. The choice with the lowest amount of waste is selected.

$$
\begin{aligned}
& \text { MWS711SF = } \\
& \text { MIN(W350S711SF, W500S711SF, WMPS711SF) }
\end{aligned}
$$

where,

$$
\begin{aligned}
\text { MWS711SF = } & \begin{array}{l}
\text { Minimum waste from packing size for a } \\
\text { small-sized family who shops every day, cooks } \\
\text { one meal per day, and cooks one dish per } \\
\text { meal }(\mathrm{g})
\end{array} \\
\mathrm{W} 350 \mathrm{~S} 711 \mathrm{SF}= & \text { Waste from } 350 \mathrm{~g} \text { packing size only }(\mathrm{g}) \\
\mathrm{W} 500 \mathrm{~S} 711 \mathrm{SF}= & \text { Waste from } 500 \mathrm{~g} \text { packing size only }(\mathrm{g}) \\
\mathrm{WMPS711SF}= & \text { Waste from mixes of } 350 \mathrm{~g} \text { and } 500 \mathrm{~g} \text { packing } \\
& \text { sizes }(\mathrm{g})
\end{aligned}
$$

Food waste may also occur during the preparation processes. According to Žitnik and Vidic [31], 11\% of the vegetable amount is wasted during food preparation, leading to "waste from preparation", as shown in Eq. (3).

$$
\mathrm{WPS711SF}=0.11 \times \mathrm{VNS711SF}
$$

where,

$$
\begin{aligned}
\text { WPS711SF = } & \text { Waste from preparation for a small-sized family } \\
& \text { who shops every day, cooks one meal per day, } \\
& \text { and cooks only one dish per meal }(\mathrm{g}) \\
\mathrm{VNS711SF}= & \text { Vegetable demand for small-sized family who shops } \\
& \text { every day, cooks one meal per day, and cooks only } \\
& \text { one dish per meal (g) }
\end{aligned}
$$

Some retailers offer various promotions to attract customers. Some promotions, however, may result in "waste from promotion". In this study, "the buy 4 get 1 free" promotion results in more food waste dumped into landfills. According to Žitnik and Vidic [31], up to $64 \%$ of food is dumped into landfills. Therefore, $64 \%$ of the promotion packs, in excess of household demand, may be dumped into landfills. Moreover, $11 \%$ of consumed promotion packs are also wasted during the preparation processes (see Eq. (4)).

$$
\text { TWEPS711SF }=(0.64 \times \mathrm{PP})+(0.11 \times 0.36 \times \mathrm{PP})
$$

where,

TWEPS711SF $=$ Waste from promotion for a small-sized family who shops every day, cooks one meal per day, and cooks only one dish per meal (g)

$\mathrm{PP}=$ Promotion packs $(\mathrm{g})$

The "household waste", as shown in Equation (5), is a summation of the three wastes, including "waste from packing size", "waste from preparation", and "waste from promotion".

$$
\begin{gathered}
\text { HOUSEHOLD WASTE }= \\
\text { MWS711SF + WPS711SF + TWEPS711SF }
\end{gathered}
$$

where,

MWS711SF $=$ Minimum waste from packing size for a small family who shops every day, cooks one meal per day, and cooks one dish per meal (g)

WPS711SF $=$ Waste from preparation for a small-sized family who shops every day, cooks one meal per day, and cooks only one dish per meal (g)

TWEPS711SF = Waste from promotion for a small-sized family who shops every day, cooks one meal per day, and cooks only one dish per meal (g)

\subsubsection{Retailer waste sub-model}

The "household demand for vegetables" in Fig. 2 is used to manage the order quantities of retailers. In this study, a new order is placed once a week to reflect the shelf life of vegetables of one week. This new order quantity is to be used to supply the household demand in the next week.

The new order quantity depends on the total "household demand for vegetables" and the order quantity last week. The total "household demand for vegetables" last week is compared with the last-week quantity. If the vegetable demand is less than the order quantity, then the new order quantity is equal to the last-week order quantity to satisfy the household demand and buffer for any demand uncertainties. In contrast, if the last-week vegetable demand is higher than the last-week order quantity, then the new order quantity is set to the last-week vegetable demand to ensure enough supply for householders (see Eq. (6)-(8)).

$$
\text { NOQ }=\text { MAX }(\text { LWHD, LWOQ })
$$

$$
\text { LWHD = HISTORY }
$$

(HOUSEHOLD DEMAND ON VEGETABLES, TIME -7) (7)

$$
\text { LWOQ }=\text { HISTORY (OQ, TIME -7) }
$$

where,

$$
\text { NOQ }=\text { New order quantity }(g)
$$


LWHD = Last-week household demand for vegetables (g)

LWOQ = Last-week order quantity (g)

$\mathrm{OQ}=$ Order quantity (g)

Food waste from retailers occurs when the buffer amount is not fully sold within a week (based on the one-week shelf life of vegetables; see Eq. (9)).

\section{RETAILER WASTE $=$ MAX \\ (0, LWOQ - HOUSEHOLD DEMAND ON VEGETABLES) (9)}

where, LWOQ = Last-week order quantity (g)

\subsubsection{Composting sub-model}

Household and retailer wastes are summed to achieve the total food waste. The total waste may be composted and used as a soil fertilizer. Based on Zulkepli et al. [16], one tonne of food waste can produce 0.2 tonne of fertilizer. The composting cost is compared with the fertilizer sales and savings in tipping fees or disposal costs at a landfill, to make composting decisions (see Eq. (10)-(14)). The capital investment of the composting plant is distributed to the annual cost, and is included in the composting cost in this study.

$$
\begin{gathered}
\text { COMPMS }=\text { FER }+ \text { TIP }- \text { COMPOP } \\
\text { FER }=\text { TOTAL WASTE } / 1000 \times 0.2 \times \text { FERPR } \\
\text { TIP }=\text { TOTAL WASTE } / 1000 \times \text { TIPPR } \\
\text { COMPOP }=\text { TOTAL WASTE } / 1000 \times \text { COMPOPU } \\
\text { DCOMP }=\text { IF }(\text { COMPMS }>0) \text { THEN } 1 \text { ELSE } 0
\end{gathered}
$$

where,

COMPMS = Savings amount of composting over investment cost (USD)

FER $=$ Fertilizer benefits (USD)

$\mathrm{TIP}=$ Savings in tipping fees (USD)

COMPOP $=$ Operating cost of composting (USD)

FERPR = Selling price of fertilizer (USD/tonne)

TIPPR = Tipping fees (USD/tonne)

COMPOPU = Operating cost of composting per unit (USD)

DCOMP $=$ Decision on composting option

\subsubsection{Anaerobic digestion sub-model}

The total food waste may be processed with anaerobic digestion to generate digestate and electricity, to be used in the community or sold to make a profit. The cost of implementing the anaerobic digestion is compared with the digestate sales, savings in tipping fees or disposal costs at a landfill, and electricity savings, to make decisions on anaerobic digestion implementation (see Eq. (15)-(18)). The capital investment of the anaerobic digestion plant is distributed to the annual cost, and is included in the implementation cost in this study.

$$
\begin{gathered}
\text { ANAEMS }=\text { FER + TIP + ECANAE - COMPOP } \\
\text { ECANAE }=\text { TOTAL WASTE } / 1000 \times 427.56 \times 0.21(16)
\end{gathered}
$$

$$
\begin{aligned}
& \text { ANAEOP }=\text { TOTAL WASTE } / 1000 \times \text { ANAEOPU } \\
& \text { DANAE }=\text { IF }(\text { ANAEMS }>0) \text { THEN } 1 \text { ELSE } 0
\end{aligned}
$$

where,

ANAEMS $=$ Savings amount of anaerobic digestion over the investment cost (USD)

FER $=$ Fertilizer benefits (USD)

TIP = Savings in tipping fees (USD)

ECANAE = electricity savings (USD)

ANAEOP $=$ Operating cost of anaerobic digestion (USD)

ANAEOPU $=$ Operating cost of anaerobic digestion per unit (USD)

DANAE $=$ Decision on anaerobic digestion option

\subsubsection{Domestic biodigester sub-model}

Biodigesters may be used before transferring food waste to landfills. The use of domestic biodigester is based on the assumption that the savings in electricity cost (by using biodigesters) is higher than the investment in the biodigester system. The total waste amount is used to calculate the total number of biodigesters that are needed in the system (see Eq. (19)). This is used to calculate the investment cost and electricity savings (see Eq. (20)-(22)). The cost of a biodigester is 150 USD [15, 51], on average. According to Romo-Rábago [30], each biodigester can produce $1.25 \mathrm{kWh} / \mathrm{d}$ of electricity, with an average electricity cost of $0.21 \mathrm{USD} / \mathrm{kWh}[16,17,52]$. The purchasing decision is then set when the savings are higher than the investment cost (see Eq. (23)).

$$
\begin{gathered}
\text { PNBD }=\text { TOTAL WASTE } \div \text { CBD } \\
\text { TICW }=\text { PNBD } \times \text { ICW } \\
\text { ECSW }=\text { MIN }((0.57 \times 0.21 \times \mathrm{AEN} \times \mathrm{HH}), \\
(0.21 \times \mathrm{PNBD} \times \mathrm{ELG})) \\
\mathrm{MS}=\mathrm{ECSW}-\mathrm{TICW} \\
\mathrm{PDBD}=\mathrm{IF} \mathrm{MS} \geq 0 \text { THEN } 1 \text { ELSE } 0
\end{gathered}
$$

where,

PNBD $=$ Number of biodigesters (units)

$\mathrm{CBD}=$ Capacity of a biodigester $(\mathrm{kg})$

TICW $=$ Total investment cost of biodigesters (USD)

ICW $=$ Investment cost of a biodigester (USD)

ECSW = Electricity savings (USD)

$\mathrm{AEN}=$ Average electricity needed per household (kWh/day)

$\mathrm{HH}=$ Number of households (families)

ELG = Electricity generated by a biodigester $(\mathrm{kWh} / \mathrm{d})$

MS = Savings amount of biodigesters over investment cost (USD)

PDBD $=$ Purchasing decision of biodigesters

If the biodigesters are purchased, then they are used for two years, reflecting their product life. During this period, no more biodigesters are added to the system. Wastes, if over the biodigesters' capacity, are sent to landfills. 


\subsubsection{Landfilling sub-model}

If composting, anaerobic digestion, or biodigesters are not utilized to reduce the amount of food waste, then the total waste is disposed of in landfills. This results in a high disposal cost, as shown in Eq. (24).

$$
\text { DISP }=\text { TOTAL WASTE } / 1000 \times \text { TIPPR }
$$

where, DISP $=$ Disposal cost (USD)

\section{Results}

\subsection{Simulation Results}

The dynamics model of food waste management is simulated, and the simulation results are shown in Fig. 3 . The results show that most waste comes from households (about $98 \%$ of the total food waste).

By using composting, anaerobic digestion, or domestic biodigesters, no food waste is dumped into landfills. This saves the disposal cost, reduces the environmental impact, and generates revenue for the community (see Fig. 4). The simulation results show that the use of anaerobic digestion brings the highest revenue over cost to the community in the long-term although this method has high investment at the beginning. The results also show that without proper food waste management, the disposal cost increases yearly, with an average growth rate of $18.6 \%$ per year.

\subsection{Sensitivity Analysis}

Closer examination of the simulation results reveals that householders are a major source of food waste. Most household wastes are from food preparation and mismatches of packing sizes (see Fig. 5). To further reduce the amount of wastes, sensitivity analysis with different percentages of waste from preparation and various packing sizes is performed to examine the amount of food waste in the long-term.

\subsubsection{Sensitivity analysis of "waste from preparation"}

According to Žitnik and Vidic [31], waste occurring during food preparation can range from a minimum of $2 \%$ to a maximum of $11 \%$. In this study, sensitivity analysis is performed with $2 \%, 6.5 \%$, and $11 \%$ of food preparation waste. The results, as shown in Fig. 6 , show that with a smaller percentage of waste in the preparation, the food waste going to a landfill decreases. The local authority and government may help in providing knowledge or guidelines on how to reduce waste in the preparation processes. EUFIC [66],

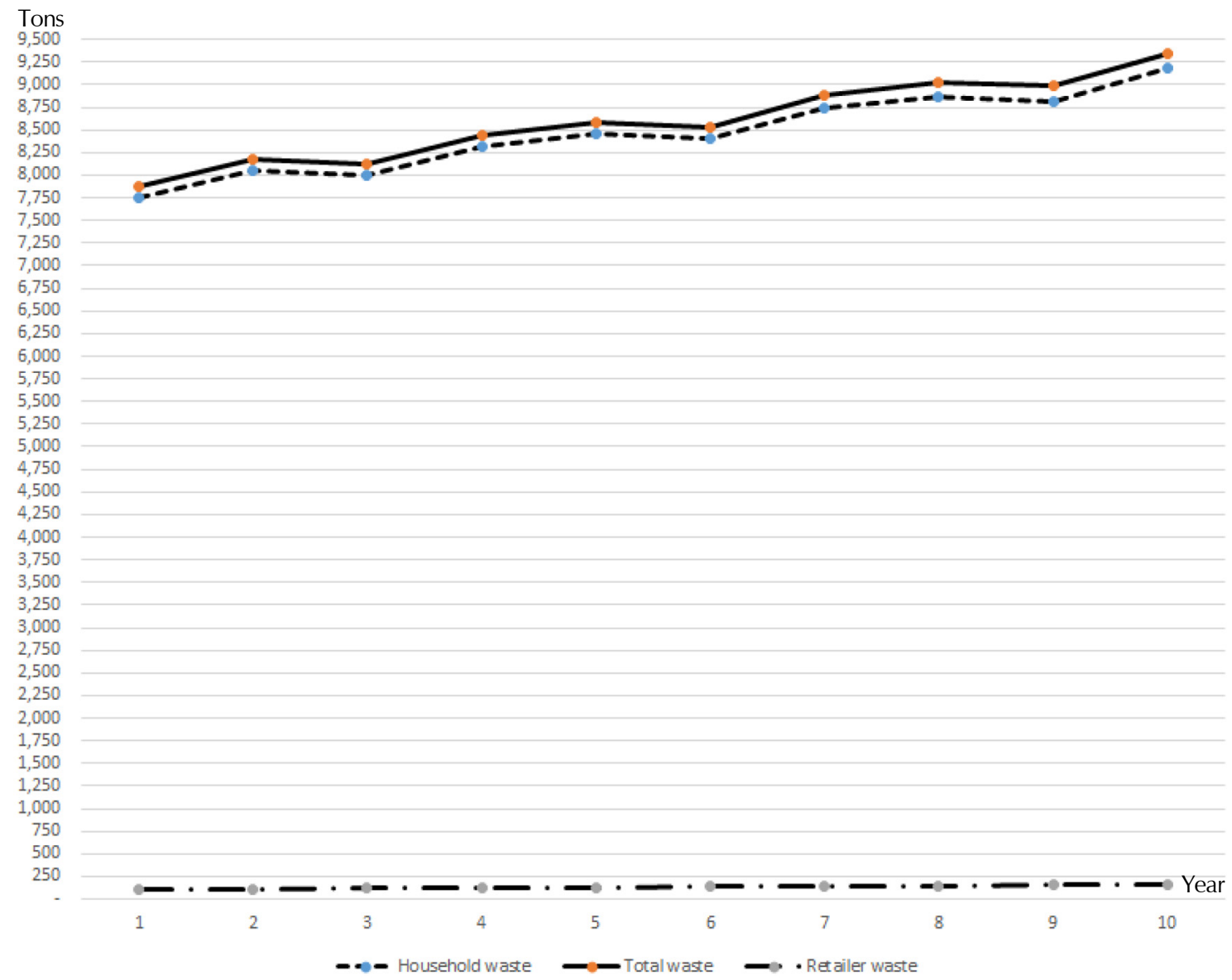

Fig. 3. Total, household, and retailer food wastes. 


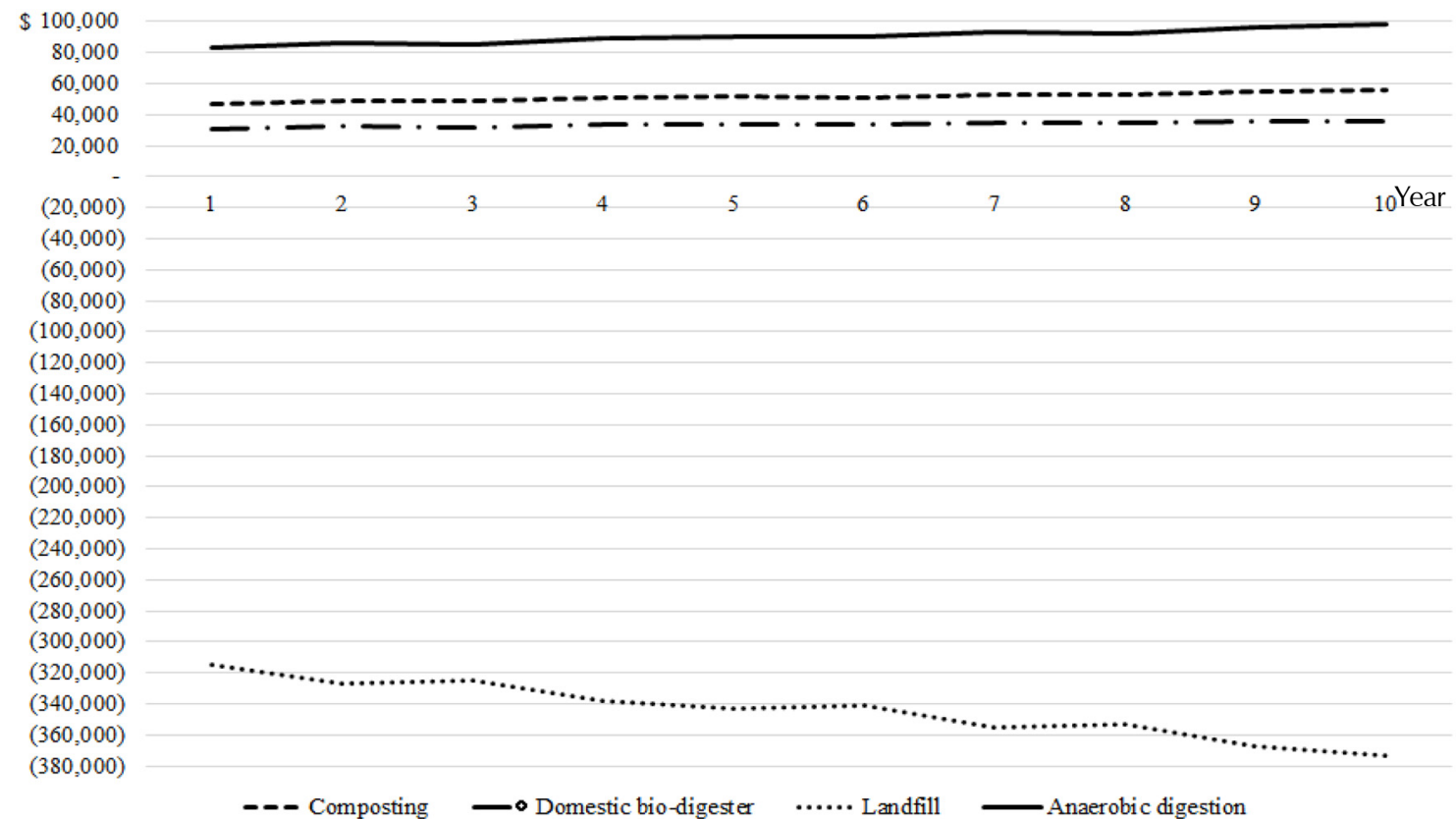

Fig. 4. Revenue over cost through the use of composting, anaerobic digestion, and domestic biodigesters.

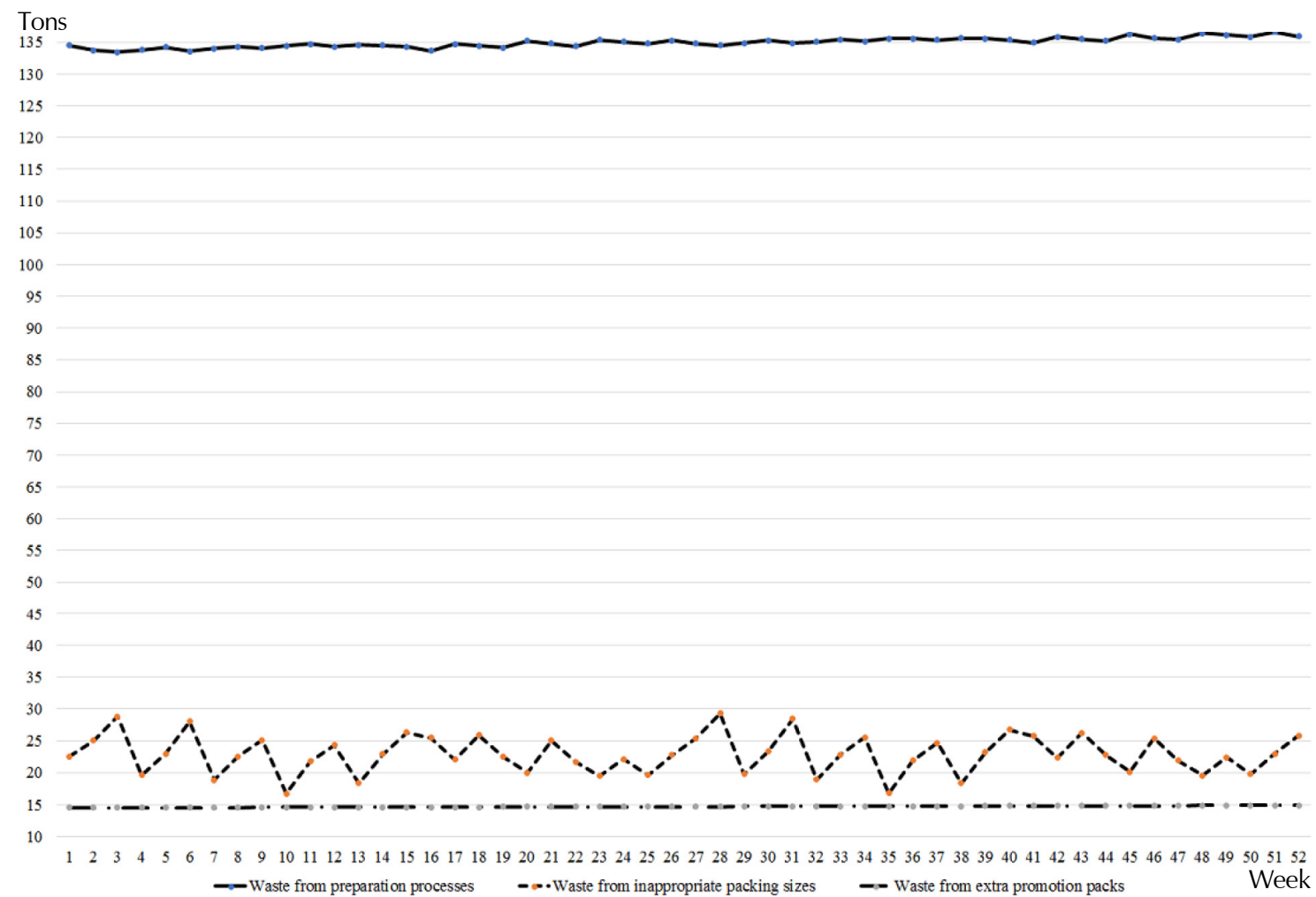

Fig. 5. Wastes from preparation, packing size, and promotion.

for example, suggested that householders should be educated in planning menus to reduce the amount of food waste. Hunter Councils [67] suggested tips to reduce the food waste during preparation, such as using the same ingredients when cooking more than one dish and being cautious while cooking to avoid dropped food and mistakes. Kubala [68] recommended using the outer layers of carrots and cucumbers, as they are edible and nutritious. This can also reduce the amount of food waste. 


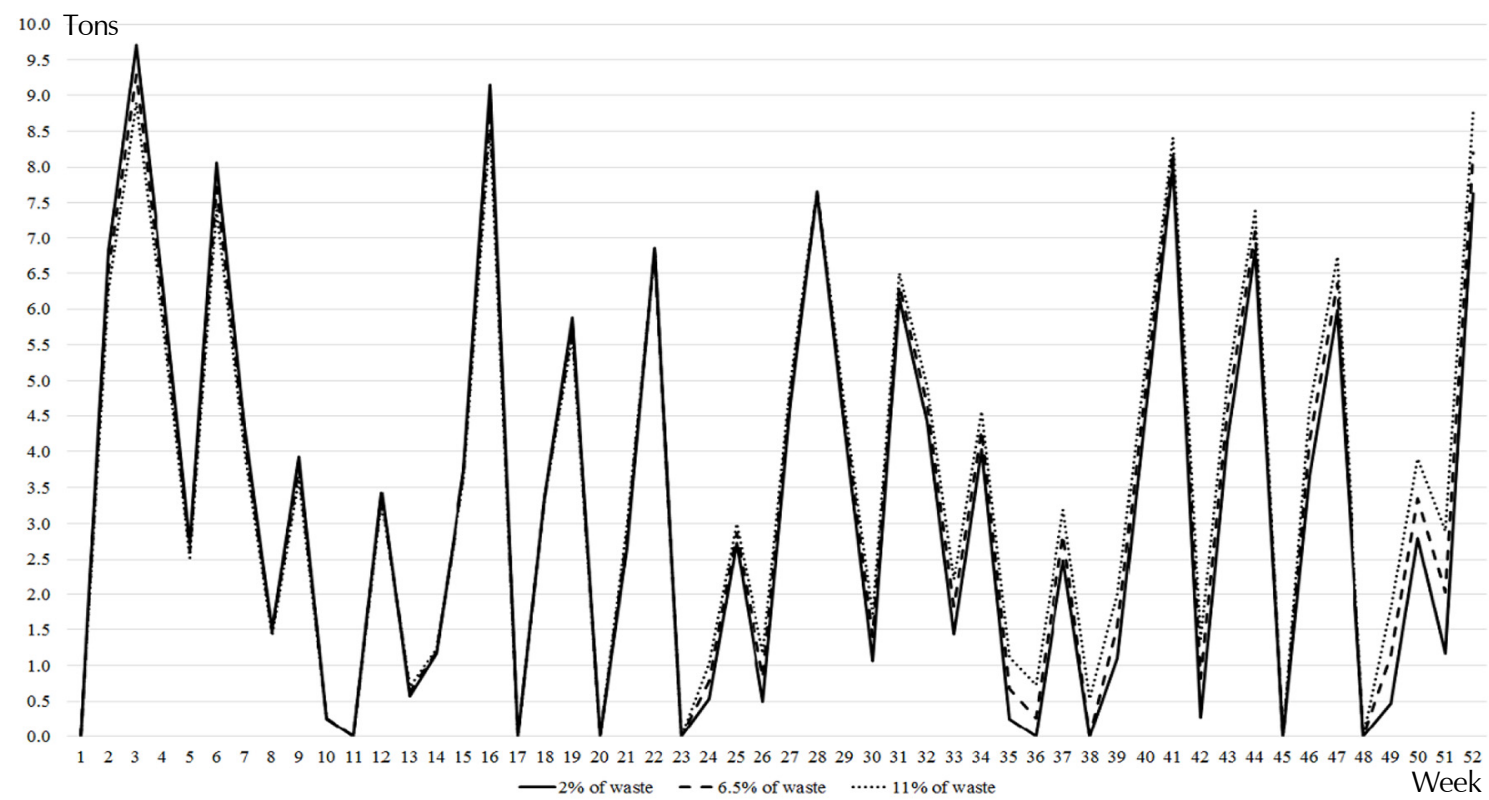

Fig. 6. Simulation results of "waste from preparation" when different percentages of waste occur in the preparation processes.

\subsubsection{Sensitivity analysis of "waste from packing size"}

Based on the interviews, possible packing sizes range from 250 $\mathrm{g}$ to $500 \mathrm{~g}$. Different packing sizes are then added to the sensitivity analysis to examine the suitable packing sizes that reduce the total food waste. The results, as shown in Fig. 7, illustrate that with small packing sizes of $250 \mathrm{~g}$ and $350 \mathrm{~g}$ packs, food wastes going to a landfill decrease. Retailers may, therefore, consider using the $250 \mathrm{~g}$ and $350 \mathrm{~g}$ packs to reduce the amount of food waste. This, however, may increase other types of waste, such as foam and plastic, as more packaging is needed for each household.

\section{Challenges and Perspectives}

Proper food waste management is needed in Phnom Penh, as the city has generated more wastes, leading to landfill scarcity and environmental problems. This study encourages the use of

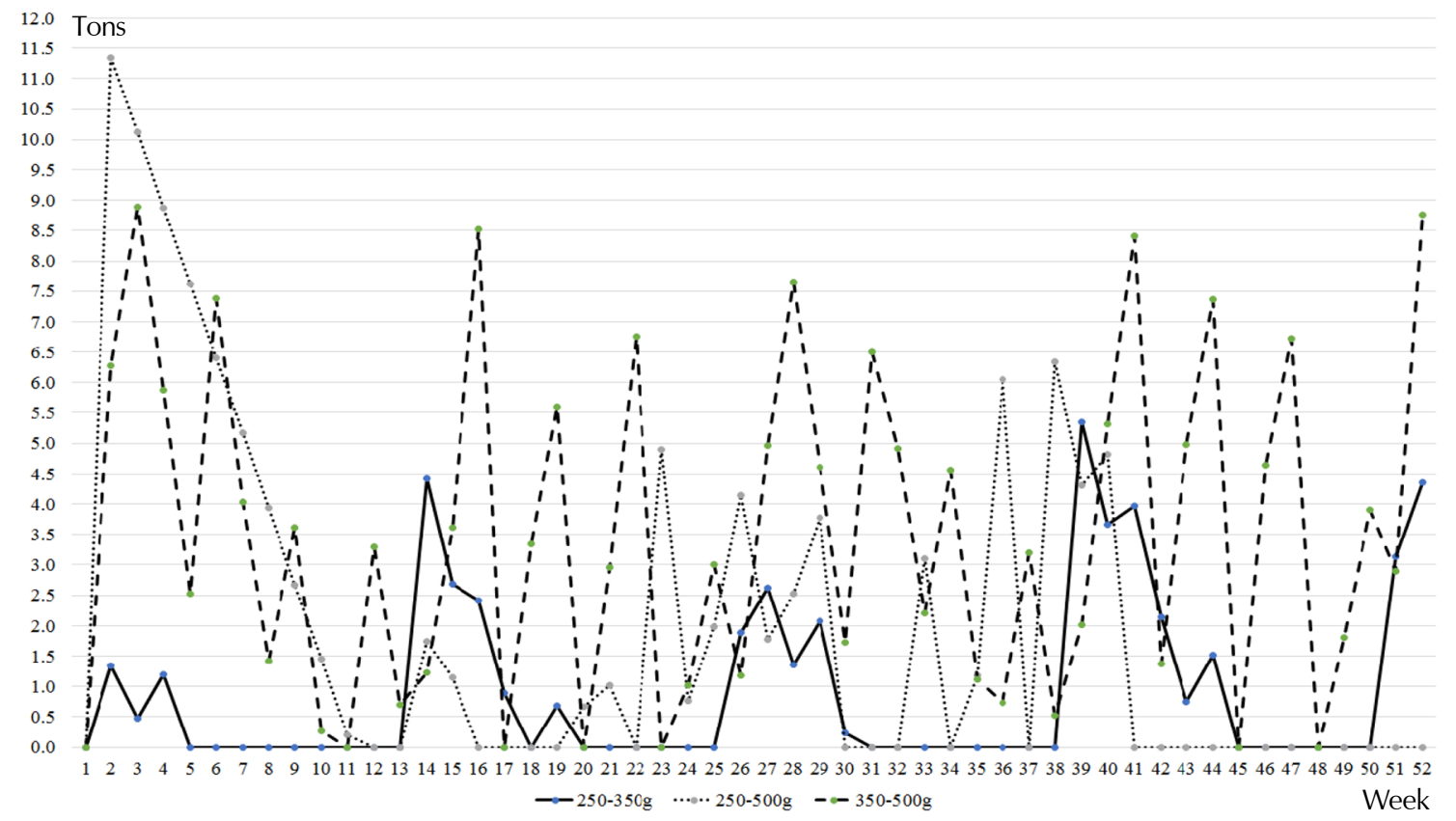

Fig. 7. Simulation results of "waste from packing size" when different packing sizes are considered. 
composting, anaerobic digestion, or domestic biodigesters to manage food waste, to reduce the amount of waste disposed of in landfills.

The challenges ahead include cooperation among households, retailers, and local authorities. This requires strong support from the upstream to the downstream of waste management. Households should consider waste generation before purchasing food. Different techniques, such as only buy what you need, use what you have, avoid serving too much, share extra food with others, and repurpose waste where possible, may help to reduce the amount of food waste [66, 69]. Retailers may consider improving inventory management, adjusting packing sizes, and partnering with farmers in the supply chain to reduce food wastes. Government campaigns may also be initiated following those established in various countries, such as banning supermarkets from throwing away unsold food in France and Italy and using technology to reduce food waste across the hospitality sector in the UAE [70]. Financial support for setting up anaerobic digestion or composting plants in a community is also needed. There is also a need for knowledge and training in food waste management.

\section{Conclusions and Recommendations}

This study utilizes the system dynamics modeling approach to develop a dynamics model of food waste management. This study considers two sources of waste, household and retailer wastes. The use of composting, anaerobic digestion, and biodigesters are considered to reduce the amount of food waste going to landfills. The simulation results reveal that most food wastes come from householders and mainly occurs during the preparation processes. Providing knowledge and tips for coaching might help to reduce the amount of food waste. Another major source of household waste is mismatched packing sizes. The use of smaller packing sizes of less than $350 \mathrm{~g}$ might help to reduce the amount of food waste.

The simulation results show the usefulness of composting, anaerobic digestion, and biodigesters in managing food waste in a community. The use of an anaerobic digestion system is found to be the most suitable method, as it saves energy costs, creates revenue from fertilizer sales, and reduces the landfill waste amount in the long term.

This study provides guidelines for food waste management in Phnom Penh in the long term. Households, retailers, local authorities, and governments may use this study to cooperate and initiate food waste management programs to reduce the amount of waste, and raise the environmental standards of the community.

This study has some limitations. Vegetables are the major source of food waste, and that is based on popular dishes. Future researches could be made, focusing on fruits, meats, and other types of food, to cover various types of food waste. Open market is also not considered in this study, as it is hard to measure exact amount of waste. Moreover, only one promotion scheme, which "buy 4 get 1 free" is used in this study. Other possible promotions may be simulated in future studies to examine the amount of food waste, and suggest appropriate promotion to be used in the supermarkets.

\section{Acknowledgments}

The authors thank AEON Cambodia Co., LTD for approving a survey entry permit.

\section{Author Contributions}

T.C. (Associate Professor) wrote the manuscript and conducted the experiments. S.T. (Master's student) conducted the experiments.

\section{References}

1. NIS. Cambodia inter-censal population survey 2013. Phnom Penh, Cambodia: Ministry of Planning; 2013.

2. NIS. General population census of the Kingdom of Cambodia 2019. Phnom Penh, Cambodia: Ministry of Planning; 2019.

3. Hul S, Kouk F, Soy T. Solid waste generation and life life-span with credible growth forecasts waste generation, volume and composition. Phnom Penh: The Asia Foundation; 2015.

4. Abdel-Shafy HI, Mansour MSM. Solid waste issue: Sources, composition, disposal, recycling, and valorization. Egyptian J. Petrol. 2018;27:1275-1290.

5. Singh RK, Premakumar DGJ, Yagasa R, Onogawa K. State of waste management in Phnom Penh, Cambodia. IGES Centre Collaborating with UNEP on Environmental Technologies (CCET) of Institute for Global Environmental Strategies (IGES). Japan: United Nations Environmental Programme; 2018.

6. Seng B, Hirayama K, Katayama-Hirayama K. Scenario analysis of the benefit of municipal organic-waste composting over landfill, Cambodia. J. Environ. Manag. 2013;114:216-224.

7. Ho KS, Chu LM. Characterization of food waste from different sources in Hong Kong. J. Air Waste Manag. Assoc. 2018;69(3): 277-288.

8. Sang-Arun J, Heng CK, Rithy U, Phalla S. A guide for technology selection and implementation of urban organic waste utilization projects in Cambodia. IGES Policy Report-2011-06. Japan: Institute for Global Environmental Strategies (IGES); 2011.

9. Russell SV, Young CW, Unsworth KL, Robinson C. Bringing habits and emotions into food waste behaviour. Resour. Conserv. Recycl. 2017;125:107-114.

10. Hoklis C, Sharp A. Greenhouse gas emission from municipal solid waste in Phnom Penh, Cambodia. GMSARN Int. J. 2014;18:73-78.

11. Hul S. Domestic waste characteristic and greenhouse gas emissions from the landfill in Phnom Penh, Cambodia. Phnom Penh: Research and Innovation Center, Institute of Technology of Cambodia; 2017.

12. Sang-Arun J, Heng CK, Pasomsouk K, Sharp A. Promoting sustainable use of waste biomass in Cambodia, Lao People's Democratic Republic, and Thailand: Combining food security, bio-energy, and climate protection benefits. Final Report for APN Project. Japan: Asia-Pacific for Global Change Research; 2010.

13. Seng B, Ochiai S, Kaneko H. Resident willingness of food waste separation in Phnom Penh, Cambodia [Internet]. [cited 24 
November 2020]. Available from: https:/www.jstage.jst.go.jp/ article/jsmcwm/23/0/23_615/_pdf.

14. Seng B, Fujiwara T, Seng B. Suitability assessment for handling methods of municipal solid waste. Global J. Environ. Sci. Manag. 2018;4(2):113-126.

15. NBP. National biodigester programme [Internet]. [cited 24 November 2020]. Available from: http://nbp.org.kh/.

16. Zulkepli NE, Muis ZA, Mahmood NAN, Hashim H, Ho WS Cost benefit analysis of composting and anaerobic digestion in a community: A review. Chemical. Eng. Transactions. 2017;56:1777-1782.

17. Chen YT. A cost analysis of food waste composting in Taiwan. Sustainability 2016;8:1-13.

18. Hul S, Kouk F, Soy T. Solid waste generation and life-span with credible growth forecast waste generation, volume and composition. Phnom Penh: The Asia Foundation; 2015.

19. Spoann V, Fujiwara T, Seng B, Lay C. Municipal solid waste management: Constraints and opportunities to improve capacity of local government authorities of Phnom Penh capital. Waste Manag Res. 2018;36(10):985-992.

20. Nomadicboys. Cambodian beef Lok Lak recipe [Internet]. [cited 10 January 2019]. Available from: https://nomadicboys.com/ cambodian-beef-lok-lak-recipe/.

21. IKnow. Cha tra kurn preng kjong (in Thai) [Internet]. [cited 8 December 2018]. Available from: https://www.iknow.com.kh/ knowledge/detail/?knowID=db3400f68083bf308bcafd672 53afaa2.53184.

22. Bongpet. Trey cha cho em (in Thai) [Internet]. [cited 8 December 2018]. Available from: http://www.bongpet.com/2016/10/00066 html.

23. Yuen M. Cambodian food: How to make salaw machu kreung [Internet]. A Wandering Foodie. [cited 8 December 2018]. Available from: https://www.awanderingfoodie.com/salawmachu-kroeung/.

24. Power Knot. Anaerobic digestion and biodigesters [Internet]. [cited 24 November 2020]. Available from: powerknot.com/ 2013/05/19/lfc-and-anaerobic-digestion/.

25. Joshi P, Visvanathan C. Sustainable management practices of food waste in Asia: Technological and policy drivers. J. Environ. Manage. 2019;247:538-550.

26. Energypedia. Types of biogas digesters and plants [Internet]. [cited 26 November 2020]. Available from: https://energypedia.info/wiki/Types_of_Biogas_Digesters_and_Plants.

27. Fakhry J. Large-scale management of unsegregated municipal solid waste in Phnom Penh: A cost comparison of three options. Seoul, Korea: Global Green Growth Institute; 2020.

28. Pai R, Rodrigues LL, Mathew AO, Hebbar S. Impact of urbanization on municipal solid waste management: A system dynamics approach. Int. J. Renew. Energy Environ. Eng. 2014;2(1):31-37.

29. Oh J, Lee H. Exploring a zero food waste system for sustainable residential building in urban areas. Environ. Eng. Res. 2018;23(1):46-53.

30. Romo-Rábago BE. Low cost biodigester as a sustainable energy solution for developing countries: Jiudai Yakou village, China, a case study. Haskayne: University of Calgary; 2014.

31. Žitnik M, Vidic T. Food among waste. Republic of Slovenia: The Statistical Office of the Republic of Slovenia; 2016.
32. Schanes K, Dobernig K, Gözet BJ. Food waste matters-A systematic review of household food waste practices and their policy implications. J. Clean. Prod. 2018;182:978-991.

33. Mongtoeun Y, Fujiwara T, Vin S. Household solid waste generation and socioeconomic factors in the capital city of Cambodia. Int. J. Environ. Sci. Natural Resour. 2019;20(1):24-27.

34. Kum V, Sharp A, Harnpornchai N. Improving the solid waste management in Phnom Penh city: A strategic approach. Waste Manag. 2005;25:101-109.

35. Bandith S. Analysis and modeling of household solid waste generation, handling, and management in Phnom Penh, Cambodia [dissertation]. Japan: Okayama Univ.; 2019.

36. World-Population-Review. Cambodia population 2019 [Internet]. [cited 10 August 2019]. Available from: http:/ worldpopulationreview.com/countries/cambodia-population/.

37. Paul F. What factors lead to food waste? [Internet]. [cited 15 November 2019]. Available from: https://waste-managementworld.com/a/what-factors-lead-to-food-waste.

38. Aschemann-Witzel J, De Hooge L, Amani P. Consumer-related food waste: Causes and potential for action. Sustainability 2015;7(6):6457-6477.

39. Aktas E, Sahin H, Topaloglu Z, Oledinma A, Huda AKS, Irani Z, Sharif AM, Wout T, Kamrava M. A consumer behavioral approach to food waste. J. Enterprise Info Manag. 2018;31(5): 658-673.

40. Evans A. Food waste behaviors: Influences and impacts on residential waste and waste reduction. Edmonton: University of Alberta; 2016.

41. Anirban M. The economics of food wastage at the consumer end. Adv. Food Technol. Nutrition. Sci. 2016;2(3):110-112.

42. Sharon F. Five strategies for food waste reduction at manufacturing and processing facilities [Internet]. JustFood. [cited 14 November 2019]. Available from: http://justfooderp.com/blog/ five-strategies-for-food-waste-reduction-at-manufacturing-and-processing-facilities/.

43. Waterlander WE, Steenhuis IH, De Boer MR, Schuit AJ, Seidell J. The effects of a $25 \%$ discount on fruits and vegetables: Results of a randomized trial in a three-dimensional web-based supermarket. Int. J. Behav. Nutrition Physic. Activity. 2012;9(1):11.

44. Morone P, Falcone PM, Imbert E, Morone M, Morone A. New consumers behaviours in the sharing economy: An experimental analysis on food waste reduction. Working Paper. Spain: Universitat Jaume-I: Università degli Studi di Bari \& UJI; 2016.

45. Le Borgne G, Sirieix L, Costa-Migeon S. Food waste and promotions. Working Paper UMR Moisa 2014-5. France: Hal 2015.

46. Segrè A, Falasconi L, Politano A, Vittuari M. Background paper on the economics of food loss and waste. Rome, Italy: Università di Bologna; 2014.

47. Chow NT. The promotion of overconsumption and food waste: A critical discourse analysis of supermarket flyers. Master dissertation. Canada: Simon Fraser University; 2016.

48. Mena C, Adenso-Diaz B, Yurt O. The causes of food waste in the supplier-retailer interface: Evidences from the UK and Spain. Resour. Conserv. Recycl. 2011;55(6):648-658.

49. Arafa M. Inventory management [Internet]. [cited 2 November 2020]. Available from: https://scholar.cu.edu.eg/?q= mahmou- 
darafa/files/inventory_management_-_3.pdf.

50. MyAccountingCourse. What is FIFO (first-in, first-out)? [Internet]. [cited 20 October 2020]. Available from: https:// www.Myaccounting course.com/accounting-dictionary/fifo-firstin-first-out.

51. Martí-Herrero J. Low cost biodigesters to produce biogas and natural fertilizer from organic waste. Geneva, Switzerland: Innovation for Development South-South Cooperation; 2008.

52. CDC. Utility cost. Phnom Penh: Council for the Development of Cambodia; 2011.

53. Dyson B, Chang N. Forecasting municipal solid waste generation in a fast-growing urban region with system dynamics modeling. Waste Manag. 2005;25(7):669-679.

54. Kum V. The bioeconomic impact of altering Mekong water flow on Tonle Sap fisheries of Cambodia: A system dynamics study. Ph.D. dissertation. Manoa: University of Hawaii; 2012.

55. Nhim T. Towards building drought resilience of rice production in Cambodia. Master dissertation. United States: Michigan State University; 2015.

56. Nguyen NH, Chinda T. A dynamic model of profit of residential projects in Vietnam. Int. J. Strat. Property Manag. 2018;22(6): 489-500.

57. Chaerul M, Tanaka M, Shekdar A. A system dynamics approach for hospital waste management. Waste Manag. 2008;28(2): 442-449.

58. Kollikkathara N, Feng H, Yu D. A system dynamic modeling approach for evaluating municipal solid waste generation, landfill capacity and related cost management issues. Waste Manag. 2010;30(11):2194-2203.

59. Sukholthaman P, Sharp A. A system dynamics model to evaluate effects of source separation of municipal solid waste management: A case of Bangkok, Thailand. Waste Manag. 2016;52: 50-61.

60. Manasakunkit C, Chinda T. Development of a municipal solid waste dynamic model in Bangkok, Thailand. Songklanakarin
J. Sci. Technol. 2017;39(5):685-695.

61. Kumar R. Research methodology: A step-by-step guide for beginners. $2^{\text {nd }}$ edition. London: Thousand Oaks; 2005.

62. Jackson SL. Research methods and statistics a critical thinking approach. U.S.A.: Thomson Wadsworth; 2003.

63. Beattie A. Cost-benefit analysis of food-waste composting program at UMM. Scholarly Horizons: U Minnesota, Morris Undergraduate J. 2014;1(1):1-14.

64. United Nations. Patterns and trends in household size and composition: Evidence from a United Nations dataset. New York: Department of Economic and Social Affairs, Population Division, United Nations; 2019.

65. Beaujouan E, Solaz A. Is the family size of parents and children still related? Revisiting the cross-generational relationship over the last century. Demography 2019;56:595-619.

66. EUFIC. 7 tips to reduce your food waste [Internet]. [cited 12 October 2020]. Available from: https://www.eufic.org/en/foodsafety/article/reducing-food-waste-yes-we-can-qa?gclid=Cj0KC QjwxNT8BRD9ARIsAJ8S5xYKY0Z5oH7dj4ICX5F5fOAWl4Go wbCWBtuUoie_AtKaFZm5eJ5UehQaAsi5EALw_wcB.

67. Hunter Councils. How to avoid food waste-food preparation. Australia: Hunter Councils Environment Division; 2015.

68. Kubala J. 20 easy ways to reduce your food waste [Internet]. Healthline. [cited 26 November 2019]. Available from: https://www.healthline.com/nutrition/reduce-food-waste\# section1.

69. Gustavsson J, Cederberg C, Sonesson U, Van Otterdijk R, Meybeck A. Global food losses and food waste. Rome: Food and Agriculture Organization of the United Nations; 2011.

70. Lemos L. How governments around the world are encouraging food waste initiatives [Internet]. Winnow. [cited 26 October 2020]. Available from: https://blog.winnowsolutions.com/howgovernments-around-the-world-are-encouraging-food-wasteinitiatives. 